\title{
Collective Reputation Effects: An Empirical Appraisal
}

\author{
Olivier Gergaud and Florine Livat*†
}

November 12, 2010

\begin{abstract}
This paper is an attempt to shed some empirical light on image linkages that exist between a collective umbrella brand and its related individual components. To tackle this issue, we estimate an interaction model in which a single collective reputation both determines and is determined by a series of individual reputations à la Tirole (1996).

From an application to Bordeaux wines using detailed survey data collected in seven European countries, we get positive and significant spillover effects from the umbrella reputation (Bordeaux) which are found to increase with the individual reputation level of the wine. Controlling for the natural endogeneity of collective reputation in this setup, allows to capture the important fact that this relationship is
\end{abstract}

${ }^{*}$ We are particularly indebted to Andrew Clark, Tom Coupé, Victor Ginsburgh, Garrett Glasgow, Abdul Noury, Frédéric Warzynski and seminar participants at the $31^{s t}$ Annual Conference of the European Association for Research in Industrial Economics, $1^{s t}$ European Conference on Cognitive Economics, $3^{\text {rd }}$ annual Conference of the American Association of Wine Economists, University of Reims and University of Paris I, for helpful comments and suggestions.

†O. Gergaud: Université de Reims Champagne-Ardenne, Reims Management School. Address: 57 bis, rue Pierre Taittinger, 51096 Reims Cedex, E-mail: olivier.gergaud@univreims.fr. F. Livat: BEM - Bordeaux Management School (CEREBEM), E-mail: florine.livat@bem.edu. 
faced with marginal diminishing returns. In other words that the marginal impact of Bordeaux as an umbrella brand actually tends to decrease to zero (and not to increase in a linear way) as the reputation level of its entities goes up. These spillover effects, when significantly positive, vary from a minimum of $5 \%$ to a maximum of $15 \%$ of additional favorable quality opinions.

Key Words: Individual Reputation, Collective Reputation, Bordeaux wines.

JEL Classification: L15 - L66 - Z13

\section{Introduction}

This paper is an attempt to shed some empirical light on image linkages that exist between a collective umbrella brand and its related individual components. This question is of importance given the major role played by reputation in daily life as recognized at least since von Hayek (1948, ch.V, p.97) and Marshall (1949, vol.4, xi $)^{1}$ but also in professional life. Indeed, a good reputation attracts clients, and often leads to higher prices through price premia for high quality products ${ }^{2}$ (Shapiro, 1983). Reputation is also viewed as a mechanism to provide incentives for agents to exert greater efforts (Mailath and Samuelson 2002, Tadelis, 2002 among others). Another strand of literature analyses how reputation encourages firms to cooperate, either by colluding with other oligopolists in price setting, providing a high quality good or by deterring other firms from entering (see Fudenberg and Tirole, 1989). Under some conditions, reputation concerns might also cause 
agents to self-select into different groups, and explain how multiple groups with different characteristics and behavioral standards can co-exist in equilibrium (Levin, 2001). For Tirole (1996) "Our welfare and our incentives depend not only on our own reputation but also on that of the groups we are associated with", (p.18). The impact of both types of reputation (individual and collective) on prices has been the focus of several applications in wine economics in recent years (e.g. Landon and Smith, 1997).

In this paper we estimate the impact of the reputation of a group on the reputation of its members. In other words, we question the existence of a collective reputation premium, a non-monetary reward that derives from the group we are associated with,a sort of collective spillover effect that would result in a positive impact on the level of individual reputation.

From an application to a sample of Bordeaux wines, we show that the magnitude of this reputation premium varies positively with the individual reputation level. In this specific context, the most reputed wine appellations are those that enjoy the highest reputation returns from the Bordeaux umbrella.

This result is in line with the theoretical predictions by Damiano et al. (2010)who showed the existence of a pecking order effect, according to which higher ranks within organizations are rewarded with more resources (promotions for instance, corner offices, etc.). We highlight such a pecking order 
effect in terms of image benefits, and in the context of a highly-reputed organization with a rate of $50 \%$ of favorable opinions among consumers.

To tackle this issue we estimate an interaction model in which a single collective reputation both determines and is determined by a series of individual reputations à la Tirole (1996). The data that we use in this application are detailed survey data concerning quality opinions on different Bordeaux wines. This survey was conducted in 2001 by Sociovision with a representative sample of 6,394 consumers from seven European countries: Belgium, Denmark, Germany, France, The Netherlands, Switzerland, United Kingdom. Information is available about the quality of Bordeaux wines in general (umbrella) and a series of nine related wines (appellations) such as Saint-Emilion, Margaux, Médoc, etc.

The paper is organized as follows. Section 2 reviews the literature briefly, Section 3 sets out the empirical model, Section 4 presents the data, Section 5 describes the empirical strategy and the results, and Section 6 draws some conclusions. 


\section{Related Literature}

\subsection{Theoretical Literature}

This paper is an attempt at testing part of Tirole's (1996) collective reputation theory. In his seminal paper, Tirole models " the idea of group reputation as an aggregate of individual reputations" considering that "a group's reputation is only as good as that of its members" (p.1). He also assumes that "belonging to a group generates a rent but is no longer a fait accompli"(p.15) and more precisely that belonging to a higher reputation group generates higher rents.

In the umbrella branding literature, collective reputation effects are analysed from the point of view of the multi-product firm. This literature is also concerned with a more specific issue: brand extension, i.e. the use of an established brand name to launch a product in a new market in order to reduce introductory costs (see Tauber, 1988). A collective brand or name may also act as a quality signal through spillovers which create reputation linkages among various products or individuals (Choi et al., 1995). In this context, individual incentives are associated with those of the group, which provides a strong commitment to maintain a high quality level for each product. Winfree and McCluskey (2005) explore, both theoretically and empirically, a market situation where several producers of a differentiated product (apples) are con- 
cerned with a single collective name at the regional level (Washington State). In such a context, where a single name is used by several producers, the collective reputation becomes a public good (non-excludable, non-rivalry) and the incentives to provide quality decrease as the size of the group increases (free riding on quality). Indeed it is impossible to exclude a producer from the benefits of the umbrella and there is non-rivalry in the sense that the use of the collective name from one producer does not prevent another one from using the same name at the same time.

The possibility for consumers to identify a range of products with the firm can provide substantial economies of scope and higher profits in equilibrium. Andersson (2002) shows that the profits made by a firm carrying a pooled reputation for producing two goods of high quality are "not smaller" than the sum of the profits of two separate firms where each one is producing a high quality good and carrying its own individual reputation ${ }^{3}$. For Wernerfelt (1988, p.459), by branding a new product, the firm does two things: it claims that both the old and the new product are of good quality, and it invites consumers to pool their experience with the two products to infer both qualities. Brand extension is efficient only when all the products under the umbrella are of good quality and therefore contribute to the umbrella's reputation. This implies that, in equilibrium, only firms producing good quality actually choose to use the umbrella branding strategy. Cabral (2000) 
gets similar results using somewhat different assumptions ${ }^{4}$. In particular, he shows that it is in the interest of firms producing a lower quality product to create a new name or reputation for the new product instead of stretching their initial reputation.

Brand extension practices, and more generally bundling a product of established quality together with one of unknown quality, can also be seen as a mechanism for informational leverage, where a firm leverages off a good's reputation in one market to mitigate the problem of informational asymmetry encountered in other markets (Choi, 1998, 2003, 2007).

According to Damanio et al. (2010), agents are usually faced with a trade-off between the peer effect and the pecking order effect when they have to decide which group to join. According to the peer effect, people desire to join organizations with high-quality members because it raises their own utility or productivity. The pecking order effect implies that they can also get advantages from their relative position or ranking in a given organization, especially when they are high up in the pecking order. The latter effect arises when resources — and presumably collective reputation impacts — are distributed among the members according to their $\operatorname{rank}^{5}$. 


\subsection{Empirical Literature}

Empirically, the notion of collective reputation has received less attention. Erdem (1998) finds that for oral-hygiene products "consumers expect the quality levels of products that are umbrella branded to be correlated highly". Sullivan (1990) provides empirical evidence for the existence of positive and negative image spillovers between the demand for products sold under the same brand name in the case of automobiles. Jarrell and Peltzman (1985) assess the effect of a product recall on the demand for this product and also on the demand for its substitutes in the case of drugs and cars. The responsible producer bears losses that are greater than the strict recall costs because of a loss of goodwill, and those losses spill over to competitors. Because of a negative externality, any favorable effect of a recall on the demand for substitutes is swamped by a more general negative effect on the industry. Borenstein and Zimmerman (1988) find that demand losses resulting from a specific airline crash affect the airline concerned as well as the main competing airlines.

In a seminal application to Bordeaux wines, Landon and Smith (1997, 1998) show that both individual and collective reputations account for a substantial fraction of price variations observed for this product. Here, the collective reputation refers to the appellation name and individual reputa- 
tions at the firm level are proxied by the average ratings the wines have received from a popular wine guide. More recently, Costanigro et al. (2009) showed in the case of the Californian wine industry that consumers are willing to pay for more information to form accurate quality expectations on specific names when prices (i.e. opportunity costs) are high, while they accept to use aggregated names for inexpensive products. Frick (2010) finds statistically significant non-linear returns for individual reputation as well as significant returns for collective reputation in the case of Mosel Valley wines. Here, collective reputation refers to two distinct consortia of wine estates (Verband Deutscher Prädikatsweingüter and Bernkasteler Ring) and not to regional or sub-regional names as in the case of Bordeaux wines analysed by Landon and Smith (1997, 1998).

\section{Empirical Model}

The empirical model discussed in this section is based on the notion of perceived quality as defined earlier by Zeithaml (1988, p.3). While objective quality can be defined as superiority or excellence, perceived quality can be viewed as the consumer's judgment about a product's overall excellence or superiority. At the aggregate level, this notion of perceived quality clearly refers to that of reputation (Shapiro, 1983). 
Letting $h$ index individual survey respondents, $i=1, \ldots, n$ index the appellations, $g$ denote the group (Bordeaux), the model is:

$$
\left\{\begin{array}{c}
q_{g}^{h}=X_{g}^{h} \beta_{g}+\sum_{i=1}^{n} q_{i}^{h} \gamma_{i}+\varepsilon_{g}^{h} \\
q_{1}^{h}=X_{1}^{h} \beta_{1}+\delta_{1} q_{g}^{h}+\varepsilon_{1}^{h} \\
\cdots \\
q_{n}^{h}=X_{n}^{h} \beta_{n}+\delta_{n} q_{g}^{h}+\varepsilon_{n}^{h}
\end{array}\right.
$$

where $q_{g}^{h}\left(\right.$ resp. $q_{i}^{h}$ ) is the quality of the group (resp. sub-appellation $i$ ) as perceived by $h, X_{g}^{h}$ and $X_{i}^{h}$ are vectors of exogenous variables including the characteristics of individual $h$ like his/her self-assessed degree of knowledge of wine, his/her region of origin, socio-professional category (upper, medium, lower incomes). These two vectors also contain information on past consumption (whether appellation $i$ or $g$ has been consumed at least once in the past 12 months or not) and a dummy variable which informs us whether consumer $h$ knows the wine or not.

$\delta_{1} \ldots \delta_{n}$ are parameters capturing the average impact of $q_{g}^{h}$, the collective reputation, on the various individual reputations $\left(q_{i}^{h}\right) \cdot \gamma_{1} \ldots \gamma_{n}$ are parameters measuring the contribution of each individual reputation to $q_{g}^{h}$. By construction, $q_{g}^{h}$ and $q_{i}^{h}$ are endogenous variables. This means that $\varepsilon_{g}^{h}$ is potentially correlated to every $q_{i}^{h}$ and $\varepsilon_{i}^{h}$ is not independent of $q_{g}^{h}$. To be estimated properly, equation (0) requires valid instruments for each $q_{i}^{h}$. As our dataset does 
not provide such variables, we will focus exclusively on the estimation of equations (1) to (n) which require instruments for $q_{g}^{h}$ only.

The instrument $\left(Z_{g}^{h}\right)$ that we use here to identify $q_{g}^{h}$ is what people surveyed think about the quality of some famous French appellations such as Alsace $\left(q_{A l}^{h}\right)$, Beaujolais $\left(q_{B e}^{h}\right)$, Burgundy $\left(q_{B u}^{h}\right)$, Côtes du Rhône $\left(q_{C r}^{h}\right)$, Languedoc-Roussillon $\left(q_{L r}^{h}\right)$ and Loire Valley $\left(q_{L v}^{h}\right)$ (see Map 1). These appellations are umbrella brands in the same way as $q_{g}^{h}$. The intuition for the validity of these instruments is that wine consumers imagine the quality of a Bordeaux by comparing it with the quality of some of its closest competitors $^{6}$. Indeed, there is reasonable chance that these opinions on Bordeaux wines will be based, among other things, on a sort of ranking of the main wines produced in France. On the other hand, while it makes sense to believe that wine consumers will compare a Bordeaux with a Beaujolais for instance (which are two regional appellations), they will not compare so naturally (i.e. frequently) a Côtes-de-Bourg which is a sub-appellation in the Bordeaux region with a regional appellation such as Burgundy. The main reason for this intuition is that Côtes-de-Bourg and Burgundy are not at the same level in the French wine classification system which is based on two types of appellations: regional (Burgundy, Bordeaux, etc.) and local/village (Côtes de Bourg, Margaux, etc.). For all of these reasons we expect these variables $\left(q_{A l}^{h}, q_{B e}^{h}, q_{B u}^{h}, q_{C r}^{h}, q_{L r}^{h}, q_{L v}^{h}\right)$ to be correlated to $q_{g}^{h}$ and independent 
of every $q_{i}^{h}$.

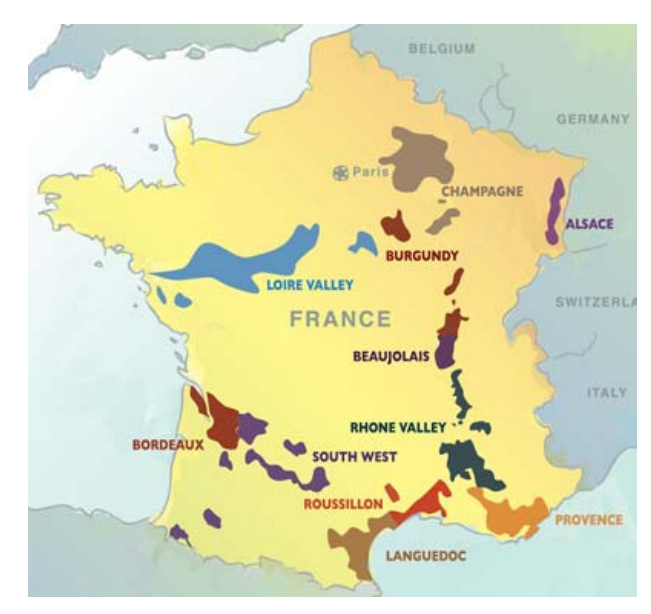

Figure 1: Wine Appellations, France

\section{Data}

Survey data were collected in 2001 in seven European countries: Belgium (1,028 wine consumers $\left.{ }^{7}\right)$, Denmark (613 wine consumers), Germany (1,133 wine consumers), France (819 wine consumers), The Netherlands (1,258 wine consumers), Switzerland (584 wine consumers), United Kingdom (959 wine consumers). The survey was conducted by Sociovision on behalf of the Comité Interprofessionnel des vins de Bordeaux. 6,394 individuals were surveyed in all.

Respondents are 46 years old on average and $51 \%$ of them are women. 
Nearly one-third (32\%) of the sample participants perceive themselves as wine connoisseurs, while $66 \%$ estimate that they are not knowledgeable in wine and $2 \%$ have no opinion. People were first invited to give their opinion on French wines in general (Alsace, Beaujolais, Bordeaux, Bourgogne, Côtes du Rhône, Languedoc-Roussillon, etc.) then on 9 Bordeaux subappellations: Bordeaux Supérieur (BSUP), Côtes de Bourg (CBG), Entredeux-Mers (E2M), Graves (GR), Margaux (MGX), Médoc (MDC), Premières Côtes de Bordeaux (PCB), Saint-Emilion (SEM) and Sauternes (SAU).

Table 1 shows the share of favorable opinions for each wine $\left(q_{i}^{h}\right.$ and $\left.q_{g}^{h}\right)$ including the instrumental variables $\left(q_{A l}^{h}, q_{B e}^{h}, q_{B u}^{h}, q_{C r}^{h}, q_{L r}^{h}, q_{L v}^{h}\right)$. This informs us about the way the quality of these wines is perceived on average in these countries. 
Table 1: Reputation levels*

\begin{tabular}{lc}
\hline \hline & \\
Bordeaux (umbrella) & 50.08 \\
& \\
Sub-Appellations within the Bordeaux Region: & \\
Bordeaux Supérieur & 25.21 \\
Entre-deux-Mers & 7.65 \\
Margaux & 19.21 \\
Médoc & 21.14 \\
Saint-Emilion & 25.6 \\
Côtes de Bourg & 7.57 \\
Graves & 19.32 \\
Premières Côtes de Bordeaux & 13.85 \\
Sauternes & 23.02 \\
& \\
French wine regions (Instruments): & \\
Alsace & 3.17 \\
Beaujolais & 17.91 \\
Bourgogne & 6.99 \\
Languedoc-Roussillon & 8.52 \\
Côtes du Rhône & 0.2 \\
Loire & 6.05 \\
& \\
\hline \hline
\end{tabular}

$\bar{*}$ * Average levels of agreement on quality (percentages)

With a level of agreement on quality higher than 50\%, Bordeaux is clearly the most appreciated French wine appellation in all Western Europe, followed by Saint-Emilion, Bordeaux Supérieur, Sauternes, Médoc. These appellations have a score of more than $20 \%$ of favorable quality opinions. The other wine regions appear to be far less well reputed, with their reputation level not exceeding 20\%. With the exception of Beaujolais (17.91\%), the other wines produced in France have reputation levels lower than $10 \%$. 


\section{$5 \quad$ Estimation procedure and Results}

As mentioned above, this dataset does not contain enough instrumental variables to identify each individual reputation $\left(q_{i}^{h}\right)$ which would be required if we were to provide unbiased estimates for every $\gamma_{i}$ parameter. Hopefully, it holds valid instruments for $q_{g}^{h}$, the group's quality as perceived by the 6,394 respondents. Therefore, we restrict the econometric analysis to the evaluation of the different umbrella impacts $\left(\delta_{i}^{\prime} s\right)$.

\subsection{Two-Stage Least Squares}

First we estimate a series of recursive models with the following structure using the 2SLS estimation procedure ${ }^{8}$ :

$$
\left\{\begin{array}{c}
q_{i}^{h}=X_{i}^{h} \beta_{i}+\delta_{i} q_{g}^{h}+\varepsilon_{i}^{h} \\
q_{g}^{h}=X_{g}^{h} \beta_{g}+Z_{g}^{h} \theta_{i}+\varepsilon_{g}^{h}
\end{array}\right.
$$

In this setup, $q_{g}^{h}$ is regressed in the collective reputation equation (0) against $X_{g}^{h}$ and the instruments $Z_{g}^{h}$; whereas $q_{i}^{h}$ is regressed against $X_{i}^{h}$ and $q_{g}^{h}$ in the individual reputation equation $(i)$. A system like this has been estimated for each of the 9 appellations beneath the Bordeaux umbrella $(i=1, \ldots, 9)$. The results are listed in Table 2 along with those of a battery of tests for the endogeneity of $q_{g}^{h}$, the validity or weakness of the instruments (Hansen's J, Stock and Yogo) in Table 3. Whenever necessary we tested the 
exogeneity of one or more questionable instruments using the "Differencein-Sargan" statistic also known as the C-Statistic. Figure 2 summarizes the results of the 2SLS procedure which does not allow us to control for the fact that the quality variables are of the binary type.

\section{[Insert Table 2 around here]}

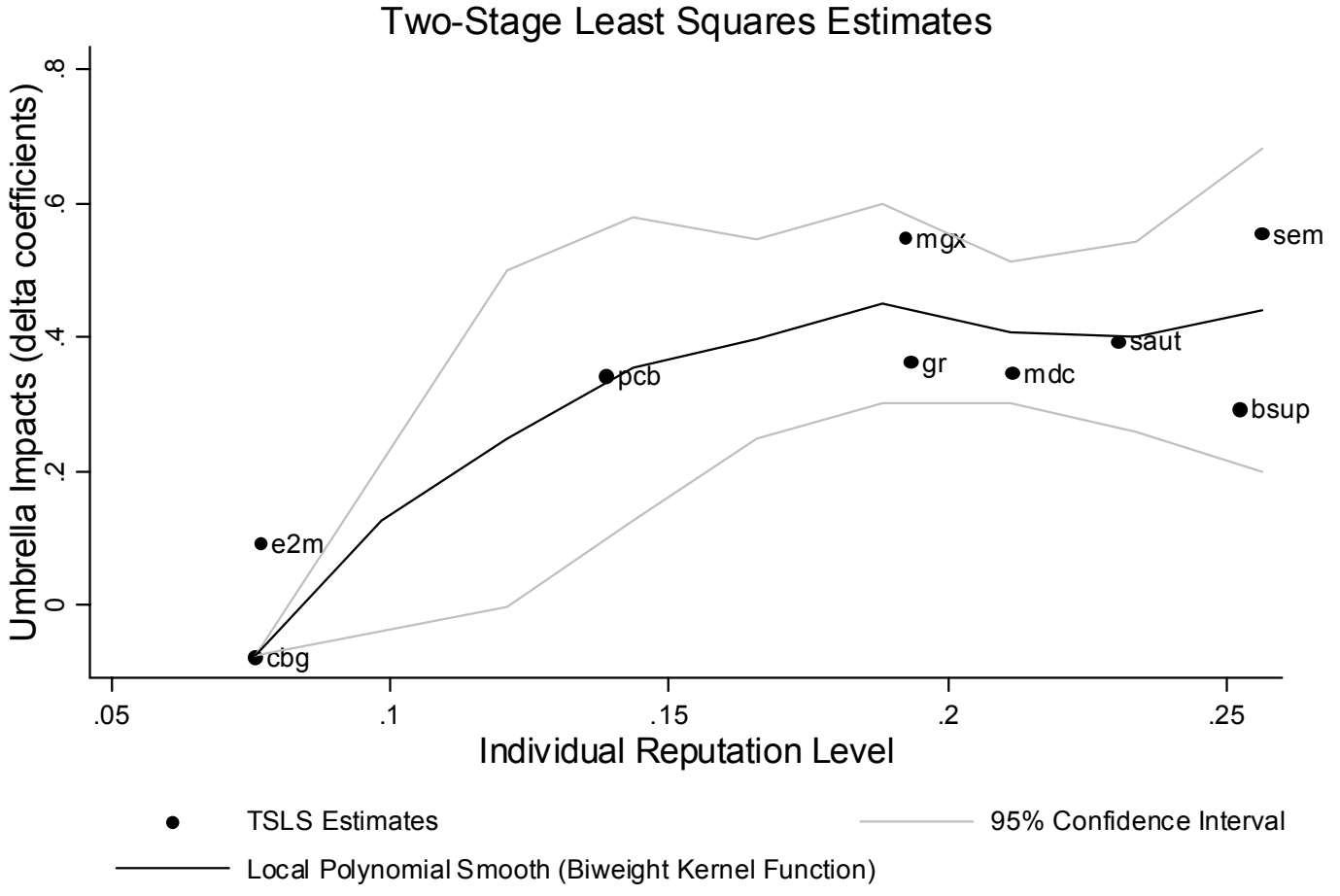

Figure 2 : Delta coefficients (2SLS)

[Insert Table 3 around here] 
The instruments $Z_{g}^{h}$ turned out to be reasonable predictors of what people think about Bordeaux as a generic appellation. Among these, Beaujolais and Languedoc-Roussillon turned out to be the most predictive (significant). ${ }^{9}$ The highest relative bias that we get (20-30\%) concerns only one regression (Côtes-de-Bourg) in which $q_{g}^{h}$ were not found endogenous. In the other regressions, the relative bias potentially induced by the weakness of the instruments is quite acceptable (between $10 \%$ and $20 \%$ in two regressions and lower than $10 \%$ in the others). The results of the various Hansen's overidentification tests failed to reject the hypothesis that the instruments are exogenous in every regression.

\subsection{Robustness check}

As a robustness check, we ran a second series of regressions using a Recursive Bivariate Probit (RBP) procedure which is more appropriate given that both $q_{i}^{h}$ and $q_{g}^{h}$ are of the binary type. The RBP results (Table 4 ) are then compared to those obtained after a regular ML probit estimation procedure (Table 5) which ignores the potential endogeneity of $q_{g}^{h}$ in each equation $i$ (see Figure 3 for ease of comparison). 


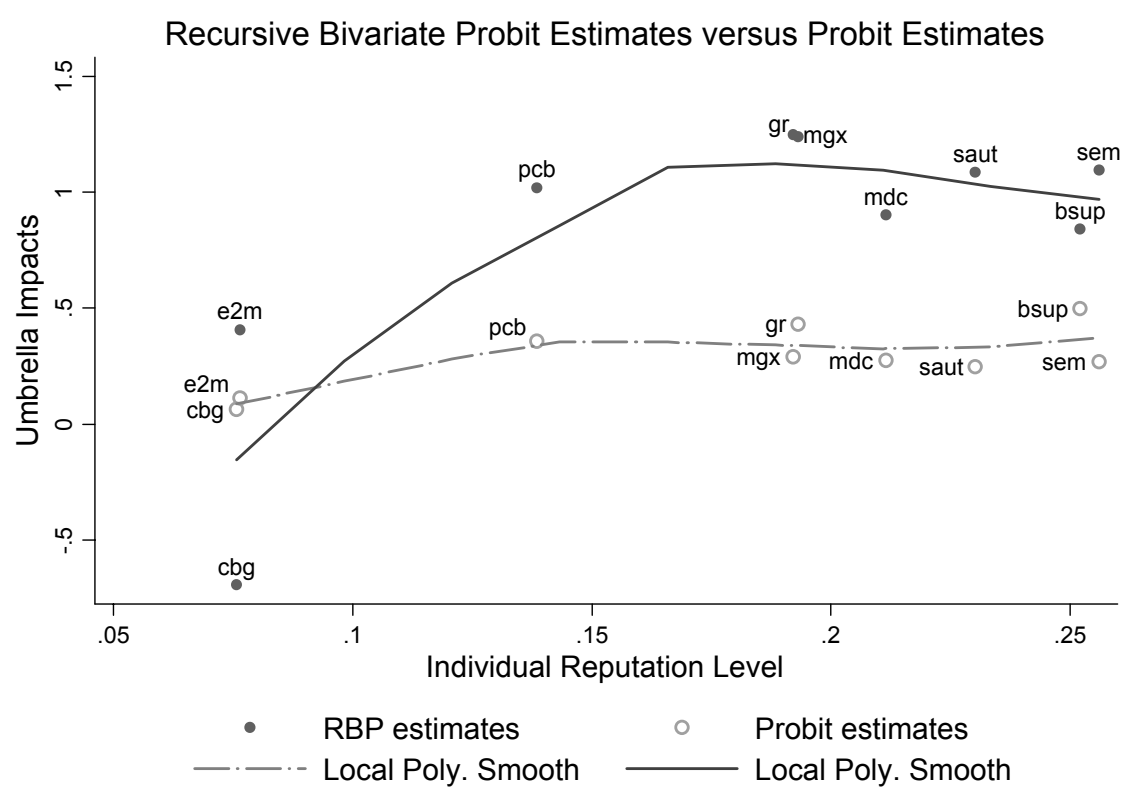

Figure 3: Delta coefficients (RBP vs. ML Probit)

\section{[Insert Tables 4 and 5 around here]}

The results are striking. $q_{g}^{h}$ came out endogenous in most systems we estimated. Indeed, in most regressions the exogeneity tests rejected the hypothesis that $q_{g}^{h}$ is exogenous. The exceptions are Côtes-de-Bourg and Entre-deux-Mers, the two less well reputed appellations (7.57\% and $7.65 \%$ respectively). Not controlling for this endogeneity pitfall results in a downward bias in the estimated returns to collective reputation. From Figure 3 we observe that ML Probit tend to systematically underestimate the various 
impacts compared with those obtained from an appropriate RBP estimation procedure. Moreover, it fails to capture the fact that this relationship exhibits marginal diminishing returns (concave shape with RBP versus more linear shape with ML Probit). In other words, the marginal impact of Bordeaux (umbrella brand) actually tends to decrease to zero (and not to increase in a linear way) as the reputation level of its entities goes up.

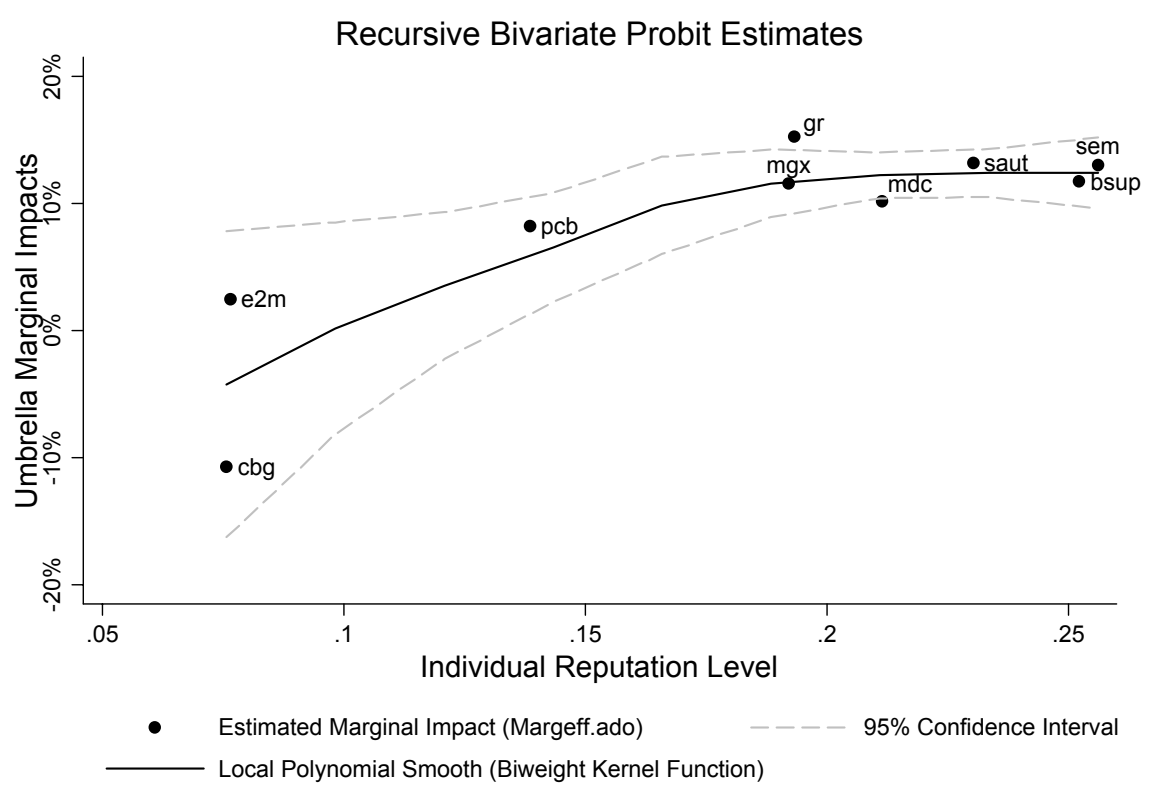

Figure 4: Marginal impacts (RBP)

We get positive and significant spillover effects from the umbrella reputation for 8 individual appellations out of 9. Highly-reputed appellations 
are found to enjoy larger umbrella impacts than less-reputed appellations. These image spillover effects when positive vary from a minimum of $5 \%$ to a maximum of $15 \%$ of additional favorable quality opinions (see Figure 4 which reproduces on the vertical axis the marginal effects in percentage points for the RBP estimates $\left.{ }^{10}\right)$.

In this group, only the leaders take a significant advantage from the high level of reputation of Bordeaux. For the followers, there is no advantage in being part of this group as they are not clearly associated to Bordeaux in the consumer's mind. This is particularly true for Entre-deux-Mers and Côtes de Bourg which do not enjoy the slightest image benefit from the fact that they are naturally Bordeaux wines. This drawback could certainly be mitigated through some specific advertising which should consists of strengthening the link between these appellations and Bordeaux in order to make it more obvious in the mind of the consumer.

\section{Conclusion}

In this paper we measured the influence of Bordeaux as a brand on a series of 9 appellations beneath this umbrella. Controlling for the fact that both types of reputation are released simultaneously, we get significant positive spillover effects from the umbrella, the magnitude of which depends positively on the 
individual reputation level of the wine under the umbrella. The reputation of this prestigious wine appellation would thus also act as a positive quality signal among a significant fraction of surveyed people in Western Europe.

Essentially, due to a lack of appropriate data and available valid instruments, in most studies brand reputation is often treated as exogenous. This paper shows that not controlling for the natural endogeneity of this variable in a simultaneous setup such as this generates downward biased estimates of those spillover effects which derive from the group's reputation.

This application is based instead on an appropriate IV estimation procedure (Recursive Bivariate Probit) which guarantees unbiased estimates of the effect of Bordeaux over the image of its main related wines. Given the difficulty in identifying each individual reputation with appropriate instruments, we focused the analysis and restricted it to measuring the effect of Bordeaux's reputation on that of its major components.

Consumers' opinions about the quality of some other famous wines produced in France (Alsace, Beaujolais, Burgundy, Côtes du Rhône, LanguedocRoussillon, Loire) have been used as instruments in order to identify the reputation of Bordeaux. These instruments proved to be valid in the sense that they are reasonably connected to Bordeaux (not weak) and not statistically related to its 9 components (exogenous).

This result is achieved in a specific environment, with a powerful umbrella 
which is at least twice as well reputed as its best reputed entities. The result could have been different had the umbrella been less influential.

Further research is clearly required to confirm these results by applying this methodology to other goods, services or individuals, although wines do seem to offer an appropriate field of application, given the presence of valid instruments as suggested in this article.

\section{Notes}

${ }^{1}$ Cited by Klein and Leffler [1981].

${ }^{2}$ Several applications of the Hedonic Price Method to wine show that a strong and positive relationship between the firm's individual reputation and the price of a bottle (see among others Landon and Smith [1998]).

${ }^{3}$ This result holds if and only if the firm has, in the past, produced a high quality product (credibilty constraint).

${ }^{4}$ In Wernerfelt [1988], brand stretching signals quality because stretching is more costly than creating a new name, whereas Cabral [2000] assumes that brand stretching is cost neutral.

${ }^{5}$ See Bar-Isaac and Tadelis (2008) for a recent and comprehensive survey on seller reputation and more specifically section 9 .

${ }^{6}$ This opinion is likely based on foreign wines too but we do not have 
information about these wines in the dataset.

${ }^{7}$ In this survey wine consumers drink wine at least once a quarter.

${ }^{8}$ For simplicity, we assume that there is no image spillovers between the different individual reputations.

${ }^{9}$ The results for the first step equations are available from the authors upon request.

${ }^{10}$ These effects were computed using Tamás Bartus' Margeff package for Stata 10 (see The Stata Journal, Volume 5 Number 3: pp. 309-329). 


\section{References}

[1] Andersson, F., 2002, 'Pooling Reputations', International Journal of Industrial Organization, 20(5), pp. 715-730.

[2] Bar-Isaac, E. and Tadelis, S., 2008, 'Seller Reputation', Foundations and Trends in Microeconomics, 4(4), 273-351.

[3] Borenstein, S. and Zimmerman, M. B., 1988, 'Market Incentives for Safe Commercial Airline Operation', The American Economic Review, 78(5), December, pp. 913-935.

[4] Cabral, L., 2000, 'Stretching Firm and Brand Reputation', Rand Journal of Economics, 31(4), Winter, pp. 658-673.

[5] Choi, C.J., Lee, S.H. and Oh, D., 1995, 'The strategy of grouping and reputation linkage in clubs and multi-products firms', European Journal of Political Economy, 11, pp. 521-533.

[6] Choi, J.P., 1998, 'Brand Extension as Informational Leverage', Review of Economic Studies, October, pp. 655-670.

[7] Choi, J.P., 2003, 'Bundling New Products with Old to Signal Quality, with Application to the Sequencing of New Products', International Journal of Industrial Organization, October, 21, pp. 1179-1200. 
[8] Choi, J.P. and Jeon, D.S., 2007,'A Leverage Theory of Reputation Building with Co-Branding: Complementarities in Reputation Building', Working Paper, Michigan State University.

[9] Damiano, E., Hao, L. and Suen W., 2010, 'First in a Village or Second in Rome?', International Economic Review, 51(1), pp. 263-288.

[10] Erdem, T., 1998, 'An Empirical Analysis of Umbrella Branding', Journal of Marketing Research, August, pp. 339-351.

[11] Frick, B., 2010, 'The Impact of Individual and Collective Reputation on Wine Prices: Empirical Evidence from the Mosel Valley', Working paper, University of Paderborn.

[12] Fudenberg, D., Tirole J., 1989, 'Noncooperative Game Theory for Industrial Organization: An Introduction and Overview', in Schmalensee, R., and Willig, R. (eds.), Handbook of Industrial Organization, vol. 1, pp. 259-327 (North Holland).

[13] Hayek, F.A., 1948, Individualism and Economic Order (University of Chicago Press, Chicago).

[14] Jarrell, G. and Peltzman, S., 1985, 'The Impact of Products Recalls on the Wealth of Sellers', Journal of Political Economy, 93(3), pp. 512-536. 
[15] Klein, B. and Leffler, K.B., 1981, 'The Role of Market Forces in Assuring Contractual Performance', Journal of Political Economy, 89 (4), pp. 61541.

[16] Landon, S. and Smith C.E., 1997, The Use of Quality and Reputation Indicators by Consumers : The Case of Bordeaux Wine', Journal of Consumer Policy, 20, pp. 289-323.

[17] Landon, S. and Smith C.E., 1998, 'Quality Expectations, Reputation and Price', Southern Economic Journal, 64, pp. 628-647.

[18] Levin, J., 2001, 'Career Concerns and Collective Reputation', Mimeo, Stanford University.

[19] Mailath, G.J. and Samuelson, L., 2002, 'Who Wants a Good Reputation ?', Review of Economic Studies, 68, pp. 415-441.

[20] Marshall, A., 1949, Principles of Economics : an Introductory Volume (Macmillan, New York, 8th edition).

[21] Shapiro, C., 1983, 'Premiums for High Quality Products as Returns to Reputations', Quarterly Journal of Economics, 98 (4), pp. 659-679.

[22] Sullivan, M., 1990, 'Measuring Image Spillovers in Umbrella-Branded Products', Journal of Business, 63(3), pp. 309-329. 
[23] Tadelis, S., 2002, 'The Market for Reputations as an Incentive Mechanism', Journal of Political Economy, August, 92(2), pp. 854-882.

[24] Tauber, E.M., 1988, 'Brand leverage: Strategy for Growth in a CostControl World', Journal of Advertising Research, August/September, pp. 26-30.

[25] Tirole, J., 1996, 'A Theory of Collective Reputations (with Applications to the Persistence of Corruption and to Firm Quality)', The Review of Economic Studies, 63(1), pp. 1-22.

[26] Wernerfelt, B., 1988, 'Umbrella Branding as a Signal of New Product Quality : an Example of Signalling by Posting a Bond', Rand Journal of Economics, 19(3), Autumn, pp. 458-466.

[27] Zeithaml, V.A., 1988, 'Consumer Perceptions of Price, Quality and Value : A Means-End Model and Synthesis of Evidence', Journal of Marketing, 53, pp. 2-22. 
Table 2: Main determinants of the individual reputation level (Two-Stage Least Squares)

\begin{tabular}{|c|c|c|c|c|c|c|c|c|c|}
\hline & $\begin{array}{l}\text { Saint } \\
\text { Emilion }\end{array}$ & $\begin{array}{l}\text { Bordeaux } \\
\text { Supérieur }\end{array}$ & Médoc & Margaux & $\begin{array}{l}\text { Entre-deux } \\
\text {-mers }\end{array}$ & $\begin{array}{c}\text { Côtes de } \\
\text { Bourg }\end{array}$ & Sauternes & $\begin{array}{l}\text { Prem. Côtes } \\
\text { de Bordeaux }\end{array}$ & Graves \\
\hline Opinion on Bordeaux Wines & $0.555^{* * *}$ & $0.293 * * *$ & $0.346^{* * *}$ & $0.547 * * *$ & $0.0920 * *$ & -0.0777 & $0.393 * * *$ & $0.341^{* * *}$ & $0.362^{* *}$ \\
\hline$(\mathrm{Good}=1 ; \mathrm{Bad}=0)$ & $(0.0918)$ & $(0.0740)$ & $(0.0743)$ & $(0.0728)$ & $(0.0439)$ & $(0.105)$ & $(0.130)$ & $(0.0884)$ & $(0.141)$ \\
\hline Past consumption : & $0.148 * * *$ & -0.0290 & $0.112^{* * *}$ & $0.176 * * *$ & $0.0298 *$ & $0.0575^{*}$ & $0.125 * * *$ & -0.00747 & 0.0616 \\
\hline Has consumed wine $i$ last year & $(0.0202)$ & $(0.0232)$ & $(0.0184)$ & $(0.0303)$ & $(0.0153)$ & $(0.0323)$ & $(0.0326)$ & $(0.0495)$ & $(0.0419)$ \\
\hline Recognition: & $0.0509 * *$ & 0.0515 & $0.0700 * * *$ & $0.222^{* * *}$ & 0.0142 & 0.0374 & $0.104 * *$ & 0.0684 & $0.125^{*}$ \\
\hline Respondent knows wine $i$ & $(0.0249)$ & $(0.0372)$ & $(0.0207)$ & $(0.0381)$ & $(0.0252)$ & $(0.0600)$ & $(0.0502)$ & $(0.0814)$ & $(0.0661)$ \\
\hline \multirow[t]{2}{*}{ Constant } & -0.0683 & $0.0746 * *$ & -0.0428 & $-0.123 * * *$ & 0.0237 & $0.160 * *$ & 0.0843 & -0.0360 & 0.105 \\
\hline & $(0.0443)$ & $(0.0376)$ & $(0.0369)$ & $(0.0377)$ & $(0.0235)$ & $(0.0804)$ & $(0.0946)$ & (0.0399) & $(0.0713)$ \\
\hline \multirow[t]{2}{*}{ Exogenous controls } & \multicolumn{9}{|c|}{ Age, Gender, Region of origin of the respondent } \\
\hline & \multicolumn{9}{|c|}{ socio-economic category, level of self-assessed wine-knowledge } \\
\hline \multicolumn{10}{|l|}{ Instruments: } \\
\hline Alsace & Yes & Yes & No & No & Yes & Yes & Yes & Yes & Yes \\
\hline Beaujolais & Yes & Yes & No & Yes & Yes & Yes & Yes & Yes & Yes \\
\hline Bourgogne & Yes & Yes & Yes & Yes & Yes & Yes & Yes & Yes & Yes \\
\hline C. du Rhône & Yes & Yes & Yes & Yes & No & Yes & Yes & Yes & Yes \\
\hline Languedoc & No & Yes & Yes & Yes & Yes & Yes & Yes & Yes & Yes \\
\hline Loire & Yes & No & Yes & No & Yes & Yes & Yes & Yes & Yes \\
\hline Excluded instruments (C-stat): & 7.662 & 8.740 & & & 4.083 & - & - & - & - \\
\hline C-stat. & $(0.0056)$ & $(0.0031)$ & & & $(0.0433)$ & - & - & - & - \\
\hline Observations & 6307 & 6307 & 6307 & 6307 & 6307 & 819 & 1382 & 3667 & 1258 \\
\hline F stat & 20.77 & 11.51 & 16.88 & 17.46 & 6.90 & 1.60 & 8.44 & 6.67 & 2.88 \\
\hline P-value & $(0.0000)$ & $(0.0000)$ & $(0.0000)$ & $(0.0000)$ & $(0.0000)$ & $(0.0500)$ & $(0.0000)$ & $(0.0000)$ & $(0.0000)$ \\
\hline
\end{tabular}

Robust standard errors in parentheses; ${ }^{* * *} p<0.01,{ }^{* *} p<0.05, * p<0.1$ 
Table 3: Exogeneity Tests and Weak Identification Tests*

\begin{tabular}{|c|c|c|c|c|c|c|c|c|c|}
\hline & $\begin{array}{c}\text { Saint } \\
\text { Emilion }\end{array}$ & $\begin{array}{l}\text { Bordeaux } \\
\text { Supérieur }\end{array}$ & Médoc & Margaux & $\begin{array}{l}\text { Entre-deux } \\
\text {-mers }\end{array}$ & $\begin{array}{c}\text { Côtes de } \\
\text { Bourg }\end{array}$ & Sauternes & $\begin{array}{l}\text { Prem. Côtes } \\
\text { de Bordeaux }\end{array}$ & Graves \\
\hline \multirow[t]{2}{*}{ Exogeneity test (Umbrella) } & 33.866 & 3.668 & 14.457 & 52.612 & 2.352 & 1.496 & 7.666 & 8.193 & 3.723 \\
\hline & $(0.0000)$ & $(0.0555)$ & $(0.0001)$ & $(0.0000)$ & $(0.1251)$ & $(0.2213)$ & $(0.0056)$ & $(0.0042)$ & $(0.0537)$ \\
\hline \multicolumn{10}{|l|}{ Weak identification test: } \\
\hline Kleibergen-Paap stat. & 18.071 & 21.509 & 23.137 & 28.261 & 23.850 & 6.454 & 7.642 & 11.119 & 7.410 \\
\hline Relative bias & $5-10 \%$ & $0 \%$ & $0 \%$ & $0 \%$ & $0 \%$ & $20-30 \%$ & $10-20 \%$ & $10-20 \%$ & $10-20 \%$ \\
\hline \multirow[t]{2}{*}{ Hansen's overid. test } & 5.107 & 7.011 & 5.465 & 5.649 & 8.050 & 2.118 & 1.128 & 6.105 & 0.321 \\
\hline & $(0.5302)$ & $(0.3198)$ & $(0.3618)$ & $(0.3419)$ & $(0.2345)$ & $(0.7140)$ & $(0.9803)$ & $(0.4115)$ & $(0.9884)$ \\
\hline Observations & 6307 & 6307 & 6307 & 6307 & 6307 & 819 & 1382 & 3667 & 1258 \\
\hline F stat & 20.77 & 11.51 & 16.88 & 17.46 & 6.90 & 1.60 & 8.44 & 6.67 & 2.88 \\
\hline P-value & $(0.0000)$ & $(0.0000)$ & $(0.0000)$ & $(0.0000)$ & $(0.0000)$ & $(0.0500)$ & $(0.0000)$ & $(0.0000)$ & $(0.0000)$ \\
\hline
\end{tabular}

Robust standard errors in parentheses; ${ }^{* * *} p<0.01,{ }^{* *} p<0.05,{ }^{*} p<0.1$

Tests based on 2SLS estimates 
Table 4: Main determinants of the individual reputation level (Recursive Bivariate Probit)

\begin{tabular}{|c|c|c|c|c|c|c|c|c|c|}
\hline & $\begin{array}{l}\text { Saint } \\
\text { Emilion }\end{array}$ & $\begin{array}{l}\text { Bordeaux } \\
\text { Supérieur }\end{array}$ & Médoc & Margaux & $\begin{array}{l}\text { Entre-deux } \\
\text {-mers }\end{array}$ & $\begin{array}{l}\text { Côtes de } \\
\text { Bourg }\end{array}$ & Sauternes & $\begin{array}{l}\text { Prem. Côtes } \\
\text { de Bordeaux }\end{array}$ & Graves \\
\hline $\begin{array}{l}\text { Opinion on Bordeaux Wines } \\
(\text { Good }=1 ; \mathrm{Bad}=0)\end{array}$ & $\begin{array}{l}0.13^{* * *} \\
(0.0216)\end{array}$ & $\begin{array}{l}0.1173^{* * *} \\
(0.0356)\end{array}$ & $\begin{array}{c}0.1013^{* * *} \\
(0.0237)\end{array}$ & $\begin{array}{c}0.1152^{* * *} \\
(0.017)\end{array}$ & $\begin{array}{l}0.0248 \\
(0.016)\end{array}$ & $\begin{array}{l}-0.1072 \\
(0.1533)\end{array}$ & $\begin{array}{l}0.1314^{* *} \\
(0.0517)\end{array}$ & $\begin{array}{l}0.082^{* * *} \\
(0.0289)\end{array}$ & $\begin{array}{l}0.1522^{* *} \\
(0.0769)\end{array}$ \\
\hline $\begin{array}{l}\text { Past consumption : } \\
\text { Has consumed wine } i \text { last year }\end{array}$ & $\begin{array}{c}0.0652^{* * *} \\
(0.0071)\end{array}$ & $\begin{array}{c}-0.008 \\
(0.0094)\end{array}$ & $\begin{array}{c}0.0509 * * * \\
(0.007)\end{array}$ & $\begin{array}{c}0.0648 * * * \\
(0.0098)\end{array}$ & $\begin{array}{l}0.0173^{* *} \\
(0.0077)\end{array}$ & $\begin{array}{l}0.053^{*} \\
(0.0308)\end{array}$ & $\begin{array}{l}0.0581 * * * \\
(0.0141)\end{array}$ & $\begin{array}{c}0.0069 \\
(0.0167)\end{array}$ & $\begin{array}{c}0.0286 \\
(0.0178)\end{array}$ \\
\hline $\begin{array}{l}\text { Recognition : } \\
\text { Respondent knows wine } i\end{array}$ & $\begin{array}{c}0.0336 * * * \\
(0.0078)\end{array}$ & $\begin{array}{c}0.0227 \\
(0.0174)\end{array}$ & $\begin{array}{c}0.0278^{* * *} \\
(0.0078)\end{array}$ & $\begin{array}{c}0.0719 * * * \\
(0.0129)\end{array}$ & $\begin{array}{c}0.0056 \\
(0.0102)\end{array}$ & $\begin{array}{c}0.0303 \\
(0.0516)\end{array}$ & $\begin{array}{l}0.0518^{* *} \\
(0.0204)\end{array}$ & $\begin{array}{c}0.0116 \\
(0.0277)\end{array}$ & $\begin{array}{c}0.0585^{* *} \\
(0.0283)\end{array}$ \\
\hline Exogenous controls & socio-economic category, level of self-assessed wine-knowledge & \multicolumn{8}{|c|}{ Age, Gender, Region of origin of the respondent } \\
\hline Instruments : & & & & & & & & & \\
\hline Alsace & Yes & Yes & No & No & Yes & Yes & Yes & Yes & Yes \\
\hline Beaujolais & Yes & Yes & No & Yes & Yes & Yes & Yes & Yes & Yes \\
\hline Bourgogne & Yes & Yes & Yes & Yes & Yes & Yes & Yes & Yes & Yes \\
\hline C. du Rhône & Yes & Yes & Yes & Yes & No & Yes & Yes & Yes & Yes \\
\hline Languedoc & No & Yes & Yes & Yes & Yes & Yes & Yes & Yes & Yes \\
\hline Loire & Yes & No & Yes & No & Yes & Yes & Yes & Yes & Yes \\
\hline Observations & 6307 & 6307 & 6307 & 6307 & 6307 & 819 & 1382 & 3667 & 1258 \\
\hline Wald test of rho $=0$ & 33.6415 & 2.97198 & 16.342 & 61.8815 & 2.32187 & 0.439661 & 7.00309 & 11.9136 & 3.09594 \\
\hline P-value & $(0.0000)$ & $(0.0847)$ & $(0.0001)$ & $(0.0000)$ & $(0.1276)$ & $(0.5073)$ & $(0.0081)$ & $(0.0006)$ & $(0.0785)$ \\
\hline Wald Chi-Sq. & 2454.82 & 1393.72 & 1860.17 & 35057.09 & 34525.19 & 140.02 & 491.23 & 30687.25 & 1881.09 \\
\hline P-value & $(0.0000)$ & $(0.0000)$ & $(0.0000)$ & $(0.0000)$ & $(0.0000)$ & $(0.0000)$ & $(0.0000)$ & $(0.0000)$ & $(0.0000)$ \\
\hline
\end{tabular}

Robust standard errors in parentheses; ${ }^{* * *} p<0.01,{ }^{* *} p<0.05,{ }^{*} p<0.1$

Coefficients correspond to marginal impacts 
Table 5: Main determinants of the individual reputation level (ML Probit)

\begin{tabular}{|c|c|c|c|c|c|c|c|c|c|}
\hline & $\begin{array}{l}\text { Saint } \\
\text { Emilion }\end{array}$ & $\begin{array}{l}\text { Bordeaux } \\
\text { Supérieur }\end{array}$ & Médoc & Margaux & $\begin{array}{l}\text { Entre-deux } \\
\text {-mers }\end{array}$ & $\begin{array}{l}\text { Côtes de } \\
\text { Bourg }\end{array}$ & Sauternes & $\begin{array}{l}\text { Prem. Côtes } \\
\text { de Bordeaux }\end{array}$ & Graves \\
\hline $\begin{array}{l}\text { Opinion on Bordeaux Wines } \\
(\operatorname{Good}=1 ; \operatorname{Bad}=0)\end{array}$ & $\begin{array}{l}0.0734^{* * *} \\
(0.0114)\end{array}$ & $\begin{array}{c}0.1467^{* * *} \\
(0.0127)\end{array}$ & $\begin{array}{c}0.0697^{* * *} \\
(0.0111)\end{array}$ & $\begin{array}{l}0.0668^{* * *} \\
(0.0105)\end{array}$ & $\begin{array}{l}0.0156 * * \\
(0.0075)\end{array}$ & $\begin{array}{l}0.0092 \\
(0.023)\end{array}$ & $\begin{array}{c}0.0713^{* * *} \\
(0.0271)\end{array}$ & $\begin{array}{l}0.0768^{* * *} \\
(0.0147)\end{array}$ & $\begin{array}{c}0.1339 * * * \\
(0.0325)\end{array}$ \\
\hline $\begin{array}{l}\text { Past consumption : } \\
\text { Has consumed wine } i \text { last year }\end{array}$ & $\begin{array}{c}0.1668 * * * \\
(0.0162)\end{array}$ & $\begin{array}{c}-0.011 \\
(0.0194)\end{array}$ & $\begin{array}{l}0.1194 \\
(0.0154)\end{array}$ & $\begin{array}{c}0.1670 * * * \\
(0.0243)\end{array}$ & $\begin{array}{l}0.0389 * * \\
(0.0167)\end{array}$ & $\begin{array}{c}0.0548 \\
(0.0349)\end{array}$ & $\begin{array}{c}0.1425 * * * \\
(0.0312)\end{array}$ & $\begin{array}{c}0.0224 \\
(0.0406)\end{array}$ & $\begin{array}{l}0.0782 * \\
(0.0454)\end{array}$ \\
\hline $\begin{array}{l}\text { Recognition } \\
\text { Respondent knows wine } i\end{array}$ & $\begin{array}{c}0.0817^{* * *} \\
(0.0188)\end{array}$ & $\begin{array}{l}0.0451 \\
(0.0362)\end{array}$ & $\begin{array}{l}0.0616 * * * \\
(0.0174)\end{array}$ & $\begin{array}{c}0.1807^{* * *} \\
(0.0327)\end{array}$ & $\begin{array}{r}0.0126 \\
(0.0220)\end{array}$ & $\begin{array}{c}0.0321 \\
(0.0559)\end{array}$ & $\begin{array}{c}0.1212 * * \\
(0.0471)\end{array}$ & $\begin{array}{c}0.0265 \\
(0.0659)\end{array}$ & $\begin{array}{c}0.1526 * * \\
(0.0700)\end{array}$ \\
\hline Exogenous controls & \multicolumn{9}{|c|}{ Age, Gender, Region of origin of the respondent } \\
\hline Observations & 6307 & 6307 & 6307 & 6307 & 6307 & 819 & 1382 & 3667 & 1258 \\
\hline $\begin{array}{l}\text { Wald Chi-Sq. } \\
\text { P-value }\end{array}$ & $\begin{array}{c}962.47 \\
(0.0000)\end{array}$ & $\begin{array}{c}563.30 \\
(0.0000)\end{array}$ & $\begin{array}{c}737.73 \\
(0.0000)\end{array}$ & $\begin{array}{r}807.04 \\
(0.0000)\end{array}$ & $\begin{array}{c}203.71 \\
(0.0000)\end{array}$ & $\begin{array}{c}29.82 \\
(0.0541)\end{array}$ & $\begin{array}{r}146.68 \\
(0.0000)\end{array}$ & $\begin{array}{c}213.44 \\
(0.0000)\end{array}$ & $\begin{array}{c}66.63 \\
(0.0000)\end{array}$ \\
\hline
\end{tabular}

Robust standard errors in parentheses; ${ }^{* * *} p<0.01,{ }^{* *} p<0.05,{ }^{*} p<0.1$; Coefficients correspond to marginal impacts. 